\title{
ANALISIS TINGKAT EFEKTIVITAS PEMBERIAN KREDIT DI BANK BPR CABANG TANGERANG
}

\author{
Tito Inneka Widyawati \\ STISIP YUPPENTEK Tangerang \\ tw_inneka@rocketmail.com
}

\begin{tabular}{|c|c|}
\hline Keyword & Abstract \\
\hline Effectiveness, Credit & $\begin{array}{l}\text { This study aims to determine the level of effectiveness of lending by PT. } \\
\text { BPR Tangerang Branch.The type of research used is quantitative } \\
\text { descriptive. Data collection techniques are carried out through } \\
\text { observation, questionnaires, interviews and documentation. } \\
\text { Determination of respondents was chosen by using purposive sampling } \\
\text { with a sample of } 70 \text { respondents. The data analysis technique used is } \\
\text { statistical analysis. The results showed that the level of attainment of the } \\
\text { percentage of the effectiveness of giving credit as a whole is in the } \\
\text { effective category ( } 82.75 \text { percent), thus it can be said that the credit } \\
\text { given by Bank PT. BPR Tangerang Branch is effective seen from the } 5 C \\
\text { principle, namely Character, Capacity, capital, Collateral, and conditon of } \\
\text { economic. Judging from the results of the measurement of the } \\
\text { Characteristics of lending effectiveness through its dimensions shows } \\
\text { that all dimensions support the effectiveness. Judging from the table } \\
\text { above I dimension is in the very effective category, namely the } \\
\text { Character dimension } 86.93 \%, 4 \text { dimensions are in the effective category, } \\
\text { namely the dimensions of Capacity } 78.14 \% \text {, capital } 82.86 \% \text { and } \\
\text { dimensions of Collateral } 84.86 \% \text {, and dimensions condition of economy } \\
\text { is } 74.7 \text { I\%. }\end{array}$ \\
\hline
\end{tabular}

(C)2018 JMB, All right reserved

\section{PENDAHULUAN}

\section{Latar Belakang Masalah}

Setiap bank dalam era perdagangan bebas menghadapi persaingan yang ketat. Meningkatnya intensitas persaingan dan jumlah pesaing menuntut bank untuk selalu memperhatikan kebutuhan dan keinginan nasabah serta berusaha memenuhi harapan nasabah dengan cara memberikan pelayanan yang lebih memuaskan daripada yang dilakukan oleh pesaing. Dengan demikian, hanya bank berkualitas yang dapat bersaing dan menguasai pasar.

Pada era globalisasi seperti sekarang ini, bank perlu mempersiapkan diri menghadapi persaingan antar bank, maka bank-bank harus lebih jeli dalam melihat peluang pasar serta keinginan dan kebutuhan dari nasabah. Bank harus dapat memberikan jasa berkualitas dengan biaya yang lebih murah dan pelayanan yang lebih baik serta dapat memuaskan kebutuhan nasabah sehingga timbul loyalitas. Bank merupakan perusahaan yang berorientasi ke masa yang akan datang, maka perusahaan harus berorientasi pada keinginan konsumennya tidak semata mata untuk mendapatkan laba.

PT. BPR Cabang Tangerang adalah perusahaan yang bergerak dibidang jasa keuangan/perbankan berdiri. Bank DPM sudah beroperasi sejak tahun 1993, dengan didukung oleh kepercayaan masyarakat yang kuat kepada integritas dan sumber daya yang dimiliki Bank tersebut, menghasilkan kinerja dan produktivitas tinggi dalam membantu masyarakat ekonomi golongan menengah ke bawah. Fungsi BPR tidak hanya sekedar menyalurkan kredit kepada pengusaha mikro, kecil, dan menengah, tetapi juga menerima simpanan dari masyarakat, 
karena proses pelayanan kreditnya yang relatif cepat, persyaratan lebih mudah dan sederhana serta diupayakan mengerti akan kebutuhan nasabahnya. Efektivitas pemberian kredit juga sangat penting karena merupakan salah satu syarat agar kredit dapat berjalan dengan lancar.

Terdapat jumlah nasabah yang mengajukan pinjaman kredit di bank BPR. Ini dapat dilihat sebagai berikut :

Tabel I. Jumlah Nasabah yang Mengajukan Fasilitas Kredit 20 I 3-20 I5

\begin{tabular}{|l|c|c|c|}
\hline \multicolumn{1}{|c|}{ Bulan } & $\mathbf{2 0 1 3}$ & $\mathbf{2 0 1 4}$ & $\mathbf{2 0 1 5}$ \\
\hline Januari & 16 & 12 & 15 \\
\hline Februari & 17 & 16 & 21 \\
\hline Maret & 16 & 15 & 24 \\
\hline April & 13 & 8 & 17 \\
\hline Mei & 17 & 20 & 23 \\
\hline Juni & 21 & 18 & 17 \\
\hline Juli & 19 & 22 & 27 \\
\hline Agustus & 25 & 29 & 14 \\
\hline September & 20 & 10 & 19 \\
\hline Oktober & 10 & 13 & 15 \\
\hline November & 12 & 24 & 19 \\
\hline Desember & 20 & 30 & 20 \\
\hline Jumlah & 206 & 217 & 231 \\
\hline
\end{tabular}

Sumber : PT.BPR 2016

Berdasarkan tabel I di atas dapat dilihat jumlah nasabah yang melakukan fasilitas kredit pada tahun 2013 sebanyak 206 nasabah, sedangkan pada tahun 2014 sebanyak 217 nasabah, terjadi kenaikan nasabah sebanyak II nasabah, dan jumlah nasabah yang melakukan fasilitas kredit pada tahun 2015 sebanyak 23I nasabah, terjadi kenaikan permintaan fasilitas kredit di PT.BPR Bank DPM sebanyak 14 nasabah. Hal ini menandakan bahwa PT.BPR Cabang Tangerang dari tahun ketahun berusaha meningkatkan pelayanan yang diberikan.

Karena efektivitas sangat berkaitan dengan tujuan yang akan dicapai maka untuk mencapai efektivitas pemberian kredit perlu diketahui tujuan pemberian kredit yang diharapkan.

\section{TINJAUAN PUSTAKA}

\section{Kredit}

Kredit yang diberikan oleh bank dapat didefinisikan sebagai penyedia uang atau tagihan yang dapat dipersamakan dengan itu, berdasarkan persetujuan atau kesepakatan pinjam meminjam antara bank dengan pihak lain yang mewajibkan pihak peminjam untuk melunasi hutangnya setelah jangka waktu tertentu dalam jumlah bunga, imbalan, atau pembagian hasil keuntungan. (Taswan, 2012 :217).

Menurut Undang -Undang No. 10 Tahun 1998 seperti dikutip oleh Sri Susilo, dkk, (2000 : 70). Kredit dapat diartikan sebagai penyediaan uang atau tagihan-tagihan yang dapat dipersamakan dengan itu berdasarkan persetujuan pinjam-meminjam antara bank dengan pihak lain dalam hal mana pihak peminjam berkewajiban melunasi hutangnya setelah jangka waktu tertentu dengan pemberian bunga.

\section{Efektivitas Pemberian Kredit}

Menurut Komarudin dalam Marbun (2006: 4I) efektivitas adalah suatu keadaan yang menunjukan tingkat keberhasilan (atau kegagalan) kegiatan manajemen dalam mencapa tujuan yang telah ditetapkan sebelumnya. Jadi dapat diaktakan bahwa efektivitas adalah hubungan antara hasil yang diperoleh dengan tujuan yang ingin dicapai suatu organisasi.

Marbun (2006: 4l) efektivitas pemberian kredit adalah tercapainya prinsip-prinsip perkreditan yang dikenal dengan $5 \mathrm{C}$, yaitu:

\section{Character}

Berkaitan dengan perilaku calon debitur mengenai keinginan untuk membayar dan memenuhi kewajiban. Biasanya perusahaan menggunakan data masa lalu mengenai track record calon debitur. Hal ini tercermin dari latar belakang hidup calon debitur baik latar belakang pekerjaan maupun yang bersifat pribadi seperti gaya hidup yang dianut, keadaan keluarga, kebiasaan dan kedudukan sosialnya. Dalam melakukan analisis mengenai watak/karakter berkaitan dengan intergritas dari calon debitur. Integritas ini sangat menentukan willingness to pay atau kemampuan membayar kembali nasabah atas kredit yang telah dinikmatinya. Penilaian terhadap itikad atau kemauan baik nasabah untuk memenuhi kewajibannya memang agak sukar untuk dilaksanakan, khususnya terhadap calon nasabah yang baru dikenal oleh bank.

2. Capacity

Menunjukkan kemampuan calon debitur untuk membayar pinjaman, yakni melunasi pokok pinjaman disertai bunga sesuai dengan ketentuan dan syarat-syarat yang 
diperjanjikan. Potensi pembayaran kewajiban debitur dapat dilihat dari histori laporan keuangan dan kinerja berupa arus kas, neraca, dan laba rugi. rasio lancar, rasio kas dan rasio efisiensi dapat menunjukkan kemampuan kemungkinan membayar. Tujuannya untuk mengetahui kemampuan membayar (willingness to ability).

\section{Capital}

Ditunjukkan oleh perbandingan antara pinjaman dan modal sendiri (ekuitas) dapat dilihat dari laporan keuangan (neraca dan laporan laba rugi) yaitu dengan melakukan pengukuran seperti dari segi likuiditas, solvabilitas, profitabilitas. Tujuannya adalah untuk mengetahui jumlah modal yang dimiliki calon debitur.

4. Collateral

Berdasarkan ketentuan yang dikeluarkan pemerintah/Bank Indonesia, setiap pemberian kredit oleh bank harus didukung oleh adanya jaminan/agunan yang memadai, kecuali untuk program-program pemerintah. Collateral atau agunan pada umumnya adalah barang barang yang disediakan peminjam kepada bank sebagai jaminan atas kredit atau jaminan yang diterimanya. Condition of Economic

Mengacu pada kondisi eksternal perusahaan yang mempengaruhi kelangsungan perusahaan. Tujuan dari penilaian ini adalah untuk mengetahui bagaimana prospek usaha calon debitur dimasa yang akan datang.

\section{Jenis dan Sumber Data}

Dalam penelitian ini, penyusun menggunakan beberapa teknik pengumpulan data dengan studi kepustakaan dan Angket

\section{Populasi dan Sampel}

Populasi dalam penelitian ini adalah pelanggan PT.BPR Cabang Tangerang sebanyak 23I nasabah. Untuk menentukan jumlah sampel, penulis menggunakan teknik pengambilan sampel dari Slovin yang dikutip oleh Umar, yaitu dengan menggunakan rumus:

Keterangan:

$$
\mathrm{n}=\frac{\mathrm{N}}{\mathrm{I}+\mathrm{N}(\mathrm{e})^{2}}
$$

$\mathrm{n}=$ ukuran/jumlah sample

$\mathrm{N}=$ ukuran populasi

$\mathrm{e}=$ persen kelonggaran ketidaktelitian tingkat kesalahan pengambilan sampelyang masih dapat ditolerir atau diinginkan, misalnya $5 \%$ sampai I5 \% (Umar, 2003: 108).

Berdasarkan rumus diatas adalah sebagai berikut :

$$
\mathrm{n}=\frac{231}{\mathrm{I}+23 \mathrm{I}(0, \mathrm{I})^{2}}=\frac{231}{3,31}=69,79=70 \text { orang }
$$

Berdasarkan perhitungan tersebut, jumlah sampel yang diambil yaitu sebanyak 70 responden.

\section{Operasional Variabel}

Untuk mempermudah pembuatan kuesioner, peneliti memerlukan indikatorindikator yang sekiranya diperlukan, seperti tabel berikut ini :

\section{METODOLOGI PENELITIAN}

\begin{tabular}{|c|c|c|}
\hline Variabel & Kriteria & Indikator \\
\hline \multirow[t]{4}{*}{$\begin{array}{c}\text { Efektivitas } \\
\text { Pemberian Kredit }\end{array}$} & Character & $\begin{array}{l}\text { 1. Saya akan membayar angsuran hutang walaupun pihak Bank } \\
\text { DPM tidak menegur atau menagih } \\
\text { 2. saya akan tetap berusaha untuk mengembalikan kredit sampai } \\
\text { lunas } \\
\text { 3. saya akan mendahulukan melunasi kredit dari pada kebutuhan } \\
\text { lainnya } \\
\text { 4. saya mempunyai kredit ditempat lain. }\end{array}$ \\
\hline & Capacity & $\begin{array}{l}\text { 1. Dalam mengansur kredit, saya menyisihkan sebagian dari } \\
\text { penghasilan yang diperoleh } \\
\text { 2. saya mempunyai penghasilan lain diluar penghasilan tetap yang } \\
\text { diperoleh }\end{array}$ \\
\hline & Capital & $\begin{array}{l}\text { I. selain meminjam di bank DPM, saya sudah memiliki modal awal } \\
\text { sebelumnya } \\
\text { 2. Penghasilan yang diperoleh, saya gunakan untuk membiayai } \\
\text { kebutuhan setiap bulan. }\end{array}$ \\
\hline & Collateral & $\begin{array}{l}\text { I. saya menulis biodata pada formulir kredit secara lengkap } \\
\text { 2. pada waktu mengajukan kredit, agunan yang saya berikan adalah } \\
\text { milik sendiri }\end{array}$ \\
\hline
\end{tabular}

Tabel 2. Operasional Variabel Penelitian 


\begin{tabular}{|l|l|l|}
\hline & \begin{tabular}{l} 
3. $\begin{array}{l}\text { kredit dapat cair setelah agunan saya selesai dinilai oleh pihak } \\
\text { bank DPM } \\
\text { 4. Agunan yang saya berikan diten ukan oleh pihak bank DPM }\end{array}$ \\
\cline { 2 - 3 }
\end{tabular} & $\begin{array}{l}\text { I. } \begin{array}{l}\text { selama mendapatpinjaman dari pihak bank DPM, saya pernah } \\
\text { mengalami musibah yang mengakibatkan pekerjaan terganggu. }\end{array} \\
\text { 2. ketentuan pemerintah berpengaruh terhadap kelancaran } \\
\text { pekerjaan sehigga saya bermasalah dalam pengambilan kredit. }\end{array}$ \\
\hline
\end{tabular}

\section{Metode Analisis Data}

Penelitian ini merupakan penelitian analisis deskriptif kuantitatif, artinya penelitian ini bermaksud mendeskripsikan atau membuat gambaran mengenai suatu variabel, gejala atau keadaan dari masing-masing variabel dan indikator. Analisis data disajikan dalam bentuk tabel yang dideskripsikan dan dianalisis dalam persentase (\%) dengan menggunakan rumus sudijono (2000:40) seperti berikut :

$$
\begin{aligned}
& P=\frac{f}{N} \times 100 \% \\
& \text { Dimana : } \\
& \mathrm{P}=\text { Persentase } \\
& \mathrm{f}=\text { Frekuensi Jawaban Responden } \\
& \mathrm{N}=\text { Jumlah sampel }
\end{aligned}
$$

Untuk menghitung pencapaian maka dilakukan analisis presentase dengan parameternya mengadopsi kategorisasi yang dikemukakan oleh Arikunto (1998) sebagai berikut :

- $86 \%-100 \%$ dikategorikan sangat efektif,

- $71 \%-85 \%$ dikategorikan efektif,

- $56 \%-70 \%$ dikategorikan cukup efektif

- $40 \%-50 \%$ dikategorikan kurang efektif dan kurang dari $40 \%$ dikategorikan tidak efektif.

\section{HASIL PENELITIAN DAN PEMBAHASAN}

\section{Dimensi Karakter (Character)}

Dimensi ini berkaitan dengan perilaku calon debitur mengenai keinginan untuk membayar dan memenuhi kewajiban di PT.BPR cabang Tangerang. Untuk mengetahui Karakter (Character), maka penulis menggunakan indikator-indikator sebagai berikut:

Tabel 3. Jawaban responden mengenai indikator pertama $(n=70)$

\begin{tabular}{|l|l|c|c|}
\hline \multicolumn{1}{|c|}{ Pernyataan } & Alternatif Jawaban & F & $\%$ \\
\hline \multirow{2}{*}{$\begin{array}{c}\text { Saya akan membayar angsuran } \\
\text { hutang walaupun pihak Bank } \\
\text { DPM tidak menegur atau } \\
\text { menagih }\end{array}$} & Sangat Setuju & 27 & 38.57 \\
\cline { 2 - 4 } & Setuju & 38 & 54.29 \\
\hline & Cukup Setuju & 5 & 7.14 \\
\hline & Tidak Setuju & 0 & 0.00 \\
\cline { 2 - 4 } & Sangat Tidak Setuju & 0 & 0.00 \\
\hline
\end{tabular}

Berdasarkan tabel 3 dapat diketahui bahwa sebagian besar responden setuju akan membayar angsuran hutang secara sadar dan sukarela. Hal ini terlihat dari hasil jawaban responden sebagian besar menyatakan setuju yaitu 38 orang dengan persentase $54,29 \%$, dan yang menyatakan sangat setuju sebanyak 27 orang dengan persentase $38,57 \%$. Indikator kedua dalam mengukur dimensi Karakter dapat dilihat pada tabel berikut :

Tabel 4. Jawaban responden mengenai indikator kedua $(n=70)$

\begin{tabular}{|l|l|c|c|}
\hline \multicolumn{1}{|c|}{ Pernyataan } & Alternatif Jawaban & F & $\%$ \\
\hline \multirow{3}{*}{$\begin{array}{l}\text { Saya akan tetap berusaha } \\
\text { untuk mengembalikan kredit } \\
\text { sampai lunas }\end{array}$} & Sangat Setuju & 43 & $6 I .43$ \\
\cline { 2 - 4 } & Setuju & 25 & 35.71 \\
\cline { 2 - 4 } & cukup Setuju & 2 & 2.86 \\
\cline { 2 - 4 } & Tidak Setuju & 0 & 0.00 \\
\cline { 2 - 4 } & Sangat Tidak Setuju & 0 & 0.00 \\
\hline \multicolumn{2}{|l|}{ Jumlah } & $\mathbf{7 0}$ & 100.00 \\
\hline
\end{tabular}

Berdasarkan tabel di atas dapat diketahui bahwa mayoritas responden menyatakan sangat setuju untuk tetap berusaha mengembalikan kredit yang dipinjamnya hingga lunas. Hal ini terlihat dari hasil jawaban responden lebih banyak memilih sangat setuju yaitu sebanyak 43 
orang dengan persentase $61,43 \%$. Indikator ketiga dalam mengukur dimensi Karakter dapat dilihat pada tabel berikut :

Tabel 5. Jawaban responden mengenai indikator ketiga $(n=70)$

\begin{tabular}{|c|l|c|c|}
\hline \multicolumn{1}{|c|}{ Pernyataan } & Alternatif Jawaban & F & $\%$ \\
\hline \multirow{4}{*}{$\begin{array}{l}\text { saya akan mendahulukan } \\
\text { melunasi kredit dari pada } \\
\text { kebutuhan lainnya }\end{array}$} & Sangat Setuju & 52 & 74.29 \\
\cline { 2 - 4 } & Setuju & 18 & 25.71 \\
\cline { 2 - 4 } & cukup Setuju & 0 & 0.00 \\
\cline { 2 - 4 } & Tidak Setuju & 0 & 0.00 \\
\cline { 2 - 4 } & Sangat Tidak Setuju & 0 & 0.00 \\
\hline \multicolumn{2}{|l}{ Jumlah } & $\mathbf{7 0}$ & $\mathbf{1 0 0 . 0 0}$ \\
\hline
\end{tabular}

Berdasarkan tabel 5 di atas dapat diketahui bahwa mayoritas responden menyatakan sangat setuju untuk mendahulukan melunasi kredit dari pada kebutuhan lainnya. $\mathrm{Hal}$ ini terlihat dari hasil jawaban responden lebih banyak memilih sangat setuju yaitu sebanyak 52 orang dengan persentase $74,29 \%$. Dalam wawancara penulis dengan responden, rata-rata responden menyatakan bahwa selama mengambil kredit, ketika mendapatkan gaji bulanan mereka akan menyisihkan untuk membayarkan hutang yang dimilikinya. Indikator keempat dalam mengukur dimensi Karakter dapat dilihat pada tabel berikut :

Tabel 6. Jawaban responden mengenai indikator keempat $(n=70)$

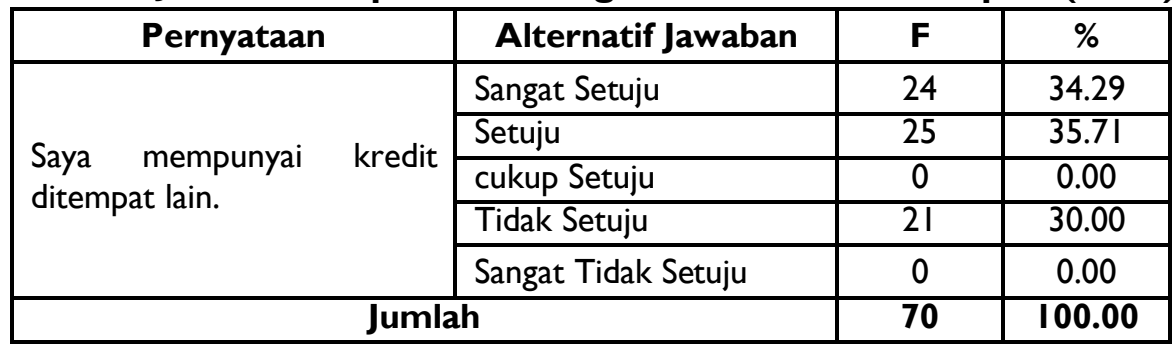

Berdasarkan tabel 6 di atas terlihat bahwa yang memiliki kredit ditempat lain ada 49 orang dan yang tidak memiliki kredit ditempat lain sebanyak 2 I orang. Hal ini membuktikan bahwa semakin banyak kebutuhan seseorang dalam hal financial, keberadaan bank pengkreditan sangat membantu masyarakat dalam memenuhi kebutuhannya seperti dalam hal mengembangkan usaha. Perhitungan indikatorindikator pada dimensi Karakter (Character) berada pada kategori sangat tinggi. Dari hal tersebut dapat disimpulkan bahwa tingkat efektivitas pemberian kredit jika dilihat dari dimensi Karakter (Character) berada pada kategori sangat tinggi.

\section{Kapasitas (Capacity)}

Dimensi ini menunjukkan kemampuan calon debitur untuk membayar pinjaman, yakni melunasi pokok pinjaman disertai bunga sesuai dengan ketentuan dan syarat-syarat yang diperjanjikan. Untuk mengetahui Dimensi kapasitas (Capacity) nasabah PT. BPR Cabang Tangerang, dapat dilihat pada tabel berikut:

Tabel 7. Jawaban responden mengenai indikator pertama $(n=70)$

Kesimpulan

\begin{tabular}{|c|c|c|c|}
\hline Pernyataan & Alternatif Jawaban & $\mathbf{F}$ & $\%$ \\
\hline \multirow{5}{*}{$\begin{array}{l}\text { Dalam mengansur } \text { kredit, } \\
\text { saya menyisihkan sebagian } \\
\text { dari penghasilan yang } \\
\text { diperoleh }\end{array}$} & Sangat Setuju & 14 & 20.00 \\
\hline & Setuju & 54 & 77.14 \\
\hline & cukup Setuju & 2 & 2.86 \\
\hline & Tidak Setuju & 0 & 0.00 \\
\hline & Sangat Tidak Setuju & 0 & 0.00 \\
\hline \multicolumn{2}{|c|}{ Jumlah } & 70 & 100.00 \\
\hline
\end{tabular}

Berdasarkan tabel 7 terlihat dari hasil jawaban responden mayoritas menyatakan setuju yaitu
54 orang dengan persentase $77,14 \%$. Hal ini membuktikan bahwa nasabah yang mengambil 
kredit di Bank BPR sangat memperhatikan untuk mengangsur kredit yang telah di ambilnya.
Indikator kedua dalam mengukur dimensi Capacity dapat dilihat pada tabel berikut :

Tabel 8. Jawaban responden mengenai indikator kedua $(n=70)$

\begin{tabular}{|l|l|c|c|}
\hline \multicolumn{1}{|c|}{ Pernyataan } & Alternatif Jawaban & F & $\%$ \\
\hline \multirow{4}{*}{$\begin{array}{l}\text { saya mempunyai penghasilan } \\
\text { lain diluar penghasilan tetap } \\
\text { yang diperoleh }\end{array}$} & Sangat Setuju & 18 & $25.7 \mathrm{I}$ \\
\cline { 2 - 4 } & Setuju & 29 & $4 I .43$ \\
\cline { 2 - 4 } & cukup Setuju & 3 & 4.29 \\
\cline { 2 - 4 } & Tidak Setuju & 20 & 28.57 \\
\cline { 2 - 4 } & Sangat Tidak Setuju & 0 & 0.00 \\
\hline \multicolumn{2}{|r}{ Jumlah } & $\mathbf{7 0}$ & 100.00 \\
\hline
\end{tabular}

Berdasarkan tabel 8 mayoritas responden mempunyai penghasilan lain diluar penghasilan tetap yang diperoleh, namun demikian masih ada 20 responden atau $28,57 \%$ responden yang hanya memiliki satu penghasilan yakni penghasilan dari pekerjaan tetapnya saja.Berdasarkan hasil perhitungan indikatorindikator pada dimensi kapasitas (Capacity) berada pada kategori tinggi.

\section{Modal (Capital)}

Dimensi ini adalah untuk mengetahui adakah modal yang dimiliki calon debitur sebelum mengambil kredit di PT. BPR Cabang Tangerang. Untuk mengetahui Dimensi modal (capital) nasabah PT. BPR Cabang Tangerang, dapat dilihat pada tabel berikut:

Tabel 9. Jawaban responden mengenai indikator pertama $(n=70)$

\begin{tabular}{|c|l|c|c|}
\hline Pernyataan & Alternatif Jawaban & F & $\%$ \\
\hline \multirow{3}{*}{$\begin{array}{l}\text { Sebelum meminjam di Bank } \\
\text { DPM, saya sudah memiliki } \\
\text { modal awal sebelumnya }\end{array}$} & Sangat Setuju & 25 & $35.7 I$ \\
\cline { 2 - 4 } & Setuju & 22 & 31.43 \\
\cline { 2 - 4 } & cukup Setuju & 0 & 0.00 \\
\cline { 2 - 4 } & Tidak Setuju & 23 & 32.86 \\
\cline { 2 - 4 } & Sangat Tidak Setuju & 0 & 0.00 \\
\hline Jumlah & $\mathbf{7 0}$ & $\mathbf{1 0 0 . 0 0}$ \\
\hline
\end{tabular}

Berdasarkan tabel 9 mayoritas responden memiliki modal awal sebelum mengambil kredit di Bank BPR. Sebanyak 47 orang yang memiliki modal awal sebelum mengambil kredit dan 23 orang yang tidak memiliki modal awal. Indikator kedua dalam mengukur dimensi modal (capital) dapat dilihat pada tabel berikut :

Tabel 10. Jawaban responden mengenai indikator kedua $(n=70)$

\begin{tabular}{|l|c|c|c|}
\hline \multicolumn{1}{|c|}{ Pernyataan } & Alternatif Jawaban & F & $\%$ \\
\hline \multirow{2}{*}{$\begin{array}{l}\text { Penghasilan yang diperoleh, } \\
\text { saya gunakan untuk } \\
\text { membiayai kebutuhan setiap } \\
\text { bulan. }\end{array}$} & Sangat Setuju & $4 I$ & 58.57 \\
\cline { 2 - 4 } & Setuju & 29 & 41.43 \\
\cline { 2 - 4 } & cukup Setuju & 0 & 0.00 \\
\hline & Tidak Setuju & 0 & 0.00 \\
\hline \multicolumn{2}{|l|}{ Sangat Tidak Setuju } & 0 & 0.00 \\
\hline \multicolumn{2}{|l|}{} & $\mathbf{7 0}$ & $\mathbf{1 0 0 . 0 0}$ \\
\hline
\end{tabular}

Berdasarkan tabel di atas $4 \mathrm{I}$ orang yang menyatakan sangat setuju atau $58,57 \%$, yang setuju sebanyak 29 orang atau $41,43 \%$. Dari hasil tersebut dapat kita simpulkan bahwa penghasilan yang dimiliki para nasabah digunakan untuk membiayai kebutuhan setiap bulannya. Berdasarkan hasil perhitungan indikatorindikator pada dimensi kapasitas (Capacity) berada pada kategori tinggi.

\section{Agunan (Collateral)}

Agunan pada umumnya adalah barang yang disediakan peminjam kepada bank sebagai jaminan atas kredit atau jaminan yang diterimanya. Untuk mengetahui tingkat efektivitas colleteraal, maka penulis menggunakan indikator-indikator sebagai berikut: 
Tabel I I. Jawaban responden mengenai indikator pertama $(n=70)$

\begin{tabular}{|l|l|c|c|}
\hline \multicolumn{1}{|c|}{ Pernyataan } & Alternatif Jawaban & F & $\%$ \\
\hline \multirow{2}{*}{$\begin{array}{l}\text { Sebelum saya mengambil } \\
\text { kredit saya mengetahui ada } \\
\text { agunan yang perlu diberikan } \\
\text { kepada Bank DPM }\end{array}$} & Sangat Setuju & $\mathbf{I I}$ & $\mathbf{I 5 . 7}$ \\
\cline { 2 - 4 } & Setuju & 23 & $\mathbf{3 2 . 8 6}$ \\
\cline { 2 - 4 } & cukup Setuju & 36 & $\mathbf{5 I . 4 3}$ \\
\cline { 2 - 4 } & Tidak Setuju & 0 & $\mathbf{0 . 0 0}$ \\
\cline { 2 - 4 } & Sangat Tidak Setuju & 0 & $\mathbf{0 . 0 0}$ \\
\hline \multicolumn{2}{|l|}{ Jumlah } & 70 & 100.00 \\
\hline
\end{tabular}

Berdasarkan tabel II sebanyak 34 orang yang mengetahui klo ada persyaratan agunan dan sebanyak 36 orang responden pada awalnya tidak mengetahui ada persyaratan agunan yang perlu diberikan kepada Bank DPM sebelum mengambil kredit. Setelah penulis melakukan wawancara ternyata hal ini disebabkan karena kurangnya informasi tertulis yang tersedia di kantor Bank BPR, sehingga responden perlu bolak-balik untuk melengkapi persyaratan yang ada. Indikator kedua dalam mengukur dimensi Collateral dapat dilihat pada tabel berikut :

Tabel I2. Jawaban responden mengenai indikator kedua $(n=70)$

\begin{tabular}{|c|l|c|c|}
\hline Pernyataan & Alternatif Jawaban & F & $\%$ \\
\hline \multirow{3}{*}{$\begin{array}{c}\text { Pada waktu mengajukan } \\
\text { kredit, agunan yang saya } \\
\text { berikan adalah milik sendiri }\end{array}$} & Sangat Setuju & 9 & 12.86 \\
\cline { 2 - 4 } & Setuju & 28 & 40.00 \\
\cline { 2 - 4 } & cukup Setuju & 33 & 47.14 \\
\cline { 2 - 4 } & Tidak Setuju & 0 & 0.00 \\
\cline { 2 - 4 } & Sangat Tidak Setuju & 0 & 0.00 \\
\hline Jumlah & $\mathbf{7 0}$ & $\mathbf{1 0 0 . 0 0}$ \\
\hline
\end{tabular}

Berdasarkan tabel 12 di atas dapat diketahui bahwa ada 37 orang yang mengajukan kredit dengan agunnan yang diberikan merupakan milik pribadi sedangkan yang menggunakan agunan milik orang lain sebanyak 33 orang. Setelah melakukan interview kepada responden ada beberapa yang menggunakan agunan milik keluarga dekatnya seperti milik suami, milik saudara dan pamannya. Indikator ketiga dalam mengukur dimensi Collateral dapat dilihat pada tabel berikut :

Tabel 13. Jawaban responden mengenai indikator ketiga $(n=70)$

\begin{tabular}{|c|l|c|c|}
\hline \multicolumn{1}{|c|}{ Pernyataan } & Alternatif Jawaban & F & $\%$ \\
\hline \multirow{3}{*}{$\begin{array}{l}\text { Kredit dapat cair setelah } \\
\text { agunan saya selesai dinilai } \\
\text { oleh pihak bank DPM }\end{array}$} & Sangat Setuju & 56 & 80.00 \\
\cline { 2 - 4 } & Setuju & 14 & 20.00 \\
\cline { 2 - 4 } & Cukup Setuju & 0 & 0.00 \\
\cline { 2 - 4 } & Tidak Setuju & 0 & 0.00 \\
\cline { 2 - 4 } & Sangat Tidak Setuju & 0 & 0.00 \\
\hline \multicolumn{2}{|l|}{ Jumlah } & $\mathbf{7 0}$ & $\mathbf{1 0 0 . 0 0}$ \\
\hline
\end{tabular}

Berdasarkan tabel 13 di atas dapat diketahui bahwa mayoritas responden mengetahui bahwa kredit yang mereka ajukan akan cair jika agunan yang dinilai pihak bank DPM Selesai. Hal ini terlihat dari hasil jawaban responden memilih sangat setuju yaitu sebanyak 56 orang dengan persentase $80 \%$ dan yang setuju sebanyak 15 orang atau $20 \%$. Indikator keempat dalam mengukur dimensi Collateral dapat dilihat pada tabel berikut :

Tabel 14. Jawaban responden mengenai indikator keempat $(n=70)$

\begin{tabular}{|l|l|c|c|}
\hline \multicolumn{1}{|c|}{ Pernyataan } & Alternatif Jawaban & F & $\%$ \\
\hline \multirow{3}{*}{$\begin{array}{l}\text { Agunan yang saya berikan } \\
\text { ditentukan oleh pihak bank } \\
\text { DPM }\end{array}$} & Sangat Setuju & 12 & 17.14 \\
\cline { 2 - 4 } & Setuju & 13 & 18.57 \\
\cline { 2 - 4 } & cukup Setuju & 45 & 64.29 \\
\cline { 2 - 4 } & Tidak Setuju & 0 & 0.00 \\
\cline { 2 - 4 } & Sangat Tidak Setuju & 0 & 0.00 \\
\hline Jumlah & $\mathbf{7 0}$ & $\mathbf{1 0 0 . 0 0}$ \\
\hline
\end{tabular}


Berdasarkan tabel I4 di atas menyatakan bahwa agunan yang diberikan ditentukan oleh pihak bank BPR sebanyak 12 orang atau $17,14 \%$ sangat setuju dan 13 orang setuju atu $18,57 \%$, sedangkan ada 45 orang atau $64,29 \%$ cukup setuju atau dengan kata lain mayoritas responden masih ragu-ragu, hal ini disebabkan karena Bank BPR bebas memberikan pilihan untuk agunan bisa berupa sertifikat tanah, surat pengangkatan pegawai, BPKB mobil, BPKB Motor. persyaratan agunan yang diberikan Bank BPR.

Berdasarkan hasil perhitungan indikatorindikator pada dimensi Collateral berada pada kategori tinggi. Dari hal tersebut dapat disimpulkan bahwa tingkat efektivitas pemberian kredit jika dilihat dari dimensi Collateral berada pada kategori tinggi.

\section{Kondisi Perekonomian (Conditions of economy)}

Dimensi kelima yang diukur adalah Kondisi perekonomian (Conditions of economy). Dimensi ini mengacu kepada kondisi ekonomi yang dimiliki calon debitur dan kondisi eksternal perusahaan yang mempengaruhi kelangsungan perusahaan. Untuk mengetahui dimensi Kondisi perekonomian (Conditions of economy) nasabah PT. BPR, dapat dilihat pada tabel berikut:

Tabel I5. Jawaban responden mengenai indikator pertama $(n=70)$

\begin{tabular}{|l|l|c|c|}
\hline Pernyataan & Alternatif Jawaban & F & $\%$ \\
\hline \multirow{2}{*}{$\begin{array}{l}\text { Selama mendapat pinjaman } \\
\text { dari pihak bank BPR, saya } \\
\text { pernah mengalami musibah } \\
\text { yang } \begin{array}{c}\text { mengakibatkan } \\
\text { pekerjaan terganggu. }\end{array}\end{array}$} & Sangat Setuju & 0 & 0.00 \\
\cline { 2 - 4 } & Setuju & 21 & 30.00 \\
\cline { 2 - 4 } & cukup Setuju & 9 & 12.86 \\
\cline { 2 - 4 } & Tidak Setuju & 40 & 57.14 \\
\cline { 2 - 4 } & Sangat Tidak Setuju & 0 & 0.00 \\
\hline \multicolumn{2}{|l}{ Jumlah } & $\mathbf{7 0}$ & $\mathbf{1 0 0 . 0 0}$ \\
\hline
\end{tabular}

Berdasarkan tabel I5dapat diketahui bahwa sebagian besar responden tidak pernah mengalami musibah yang mengakibatkan pekerjaan terganggu, ya $\mathrm{Hal}$ ini membuktikan bahwa nasabah yang mengambil kredit di Bank BPR sangat memperhatikan untuk mengakni ada 40 orang atau sekitar $57,14 \%$, namun ada pula yang pernah mengalami musibah, setelah melakukan wawancara kepada responden ternyata ada diantara responden yang pernah mengalami kecelakaan kerja ditempat kerjanya sehingga dia harus istirahat, hal ini mempengaruhi pembayaran angsuran hutang yang terlambat selama dua bulan. Indikator kedua dalam mengukur dimensi Conditions of economy dapat dilihat pada tabel berikut :

Tabel 16 Jawaban responden mengenai indikator kedua $(n=70)$

\begin{tabular}{|l|l|c|c|}
\hline \multicolumn{1}{|c|}{ Pernyataan } & Alternatif Jawaban & F & $\%$ \\
\hline \multirow{2}{*}{$\begin{array}{l}\text { Ketentuan pemerintah } \\
\text { berpengaruh terhadap } \\
\text { kelancaran pekerjaan sehigga } \\
\text { saya bermasalah dalam } \\
\text { pengambilan kredit. }\end{array}$} & Sangat Setuju & 14 & 20.00 \\
\cline { 2 - 4 } & Setuju & 56 & 80.00 \\
\cline { 2 - 4 } & cukup Setuju & 0 & 0.00 \\
\hline & Tidak Setuju & 0 & 0.00 \\
\cline { 2 - 4 } & Sangat Tidak Setuju & 0 & 0.00 \\
\hline \multicolumn{2}{|l|}{ Jumlah } & $\mathbf{7 0}$ & $\mathbf{1 0 0 . 0 0}$ \\
\hline
\end{tabular}

Berdasarkan tabel di atas dapat diketahui bahwa mayoritas responden menganggap bahwa ketentuan pemerintah berpengaruh terhadap kelancaran pekerjaan. $\mathrm{Hal}$ ini terlihat dari sikap responden yang memilih sangat setuju sebanyak 14 orang atau $20 \%$ dan setuju sebanyak 56 orang atau $80 \%$.

Berdasarkan hasil perhitungan indikatorindikator pada dimensi kapasitas (Capacity) berada pada kategori tinggi. Dari hal tersebut dapat disimpulkan bahwa tingkat efektivitas pemberian kredit jika dilihat dari dimensi Conditions of economy berada pada kategori tinggi.

\section{KESIMPULAN DAN SARAN}

\section{Kesimpulan}

Dilihat dari hasil pengukuran karakteristik efektivitas pemberian kredit melalui dimensinya 
menunjukkan bahwa semua dimensi mendukung efektivitas tersebut. Dimensi berada pada kategori sangat efektif yaitu, dimensi character, empat dimensi berada pada kategori efektif yaitu dimensi Capacity, capital dan dimensi collateral serta dimensi condition of economy. Hasilpenelitian ini dapat memperkuat mengenai pentingnya penerapan prinsip $5 \mathrm{C}$ yaitu character, Capacity, capital, collateral, dan conditon of economic.

\section{Saran}

Secara keseluruhan efektivitas pemberian kredit berada pada persentase yang tinggi, dapat diartikan indikator pada masing-masing dimensi dan menunjang efektivitas pemberian kredit. dengan begitu diharapkan sebaiknya PT. BPR Cabang Tangerang bisa mempertahankan analisis pemberian kredit dengan prinsip 5C sehingga pemberian kredit semakin efektif.

\section{DAFTAR PUSTAKA}

Hasibuan, Malayu S.P. 2005. Manajemen Sumber Daya Manusia Edisi Revisi. Jakarta: Bumi Aksara

Kasmir. 2002. Bank dan Lembaga Keuangan Lainnya. Jakarta : PT. Raja Grafindo Persada

Kasmir. 2005. Dasar-Dasar Perbankan. Jakarta : Raja Grafindo Persada

Marbun. Anderson. 2006. Peranan Pengendalian Intern Dalam Menunjuang Efentivitas Sistem Pemberian Kredit Usahan Kecil Menengah. (Studi kasus pada Koperasi Simpan Pinjam Atha Jaya Sentosa Jakarta). Skripsi Fakultas Ekonomi Universitas Widyatama.

Moleong, J Lexy. 2007. Metode Penelitian Kualitatif.Bandung : PT. Remaja Rosdakarya

Susilo, Sri Y. 2000. Bank dan Lembaga Keuangan Lain. Jakarta : Salemba Empat

Sudijono, Anas. 2000. Pengantar Administrasi Pembangunan. Jakarta : rajawali

Taswan. 20I2. Manajemen Perbankan Konsep, Teknik, dan Aplikasi Edisi Kedua. Yogyakarta : UPP STIM YKPN 